\title{
PEMANFAATAN DATA IKLIM UNTUK EVALUASI KEKERINGAN DENGAN MENGGUNAKAN INDEKS PALMER
}

\author{
Oleh : Sudibyakto *
}

ABSTRACT

The aim of this research was to evaluate the drought severity using the Palmer's Drought Index. The study area covers from the coastal area, low land area, and the Central Java. Data used in this study were mean monthly rainfall dan temperature in the period of 1972 to 1976, and soil water avalibility. Rainfall data was derived from 69 stations. The water galance concept of two soil layers was used in the prediction of the droughness.

The results show that in the forested area with clayed soil the drought severity was lately after a month eith no rainfall. However, the correlation coefficient $(r)$ of rainfall and drought index was higher than a lagcorrelation coefficient $(r L)$. The feasibility of drought index should be verified by using the agricultural production of rainfed areas and the flooded areas.

\section{INTISARI}

Tujuan penelitian ini ialab mengevaluasi tingkat kekeringan di daerab Kedu Selatan, Jawa Tengab dengan menggunakan Indeks Palmer, dengan harapan agar dapat diperoleb gambaran bubungan antara curab bujan dan indeks kekeringan. Data yang digunakan adalab curab bujan dan subu udara rataan bulanan selama 5 tabun (antara 1972 dan 1976) dan air tanab yang tersedia pada kedua lapisan tanab atas. Data bujan diambil dari 69 stasiun penakar bujan biasa. Data klimatologi diperoleh dari stasiun Sempor dan hasil akbir berupa Peta Indeks kekeringan.

Hasil perbitungan indeks kekeringan atas data bujan di suatu lokasi menimbulkan indeks yang terlalu basab atau terlalu kering dari keadaan normalnya untuk di suatu tempat. Hubungan dua deret waktu antara bujan dan indek kekeringan menunjukkan babwa daerab yang berbutan dengan kondisi tanabnya berupa tanab liat, timbulnya kekeringan mengalami kemunduran setelab beberapa bulan tidak terjadi bujan. 
Sebagian besar koefisien korelasi ( $r$ ) menunjukkan nilai yang lebib besar daripada koefisien korelasi-lag ( $r L)$, kecuali di daerah yang mempunyai kawasan butan cukup luas.

Kelayakan Peta Indeks kekeringan dapat dikaitkan dengan penurunan produksi pertanian (padi ladang) dan peristiwa banjir yang pernab terjadi di daerab penelitian.

\section{PENDAHULUAN}

\section{Latar Belakang}

Manfaat hasil analisis data cuaca iklim terutama di bidang pertanian akhir-akhir ini semakin dirasakan manfaatnya di Indonesia sehubungan dengan usaha mencapai kecukupan pangan bagi penduduk. Iklim seperti halnya dengan lahan harus dipandang sebagai salah satu sumberdaya, tetapi iklim merupakan salah satu sumberdaya alam yang sukar untuk dimanipulasi (Rijks, 1979).

Dari beberapa faktor penentu hasil tanaman, cuaca dan iklim merupakann faktor yang belum dapat dikendalikan. Manusia hingga saat ini hanya mampu mengusahakan penyesuaian kegiatannya terhadap faktor ini (Chambers, 1979). Lebih jauh Rijk (1979) menyatakan bahwa sifat cuaca dan iklim di daerah tropika, fluktuasinya akan berpengaruh langsung pada produksi pertanian.

Salah satu unsur terpenting dalam pencirian iklim suatu daerah adalah air, ia merupakan sumberdaya alam yang bersumber pada hujan. Menyadari bahwa agihan hujan selalu tidak pernah merata di setiap tempat dan waktu, maka akan terjadi perbedaan tingkat kekeringan antara satu tempat dengan tempat lainnya.

Banjir dan kekeringan sebagai akibat perubahan musim merupakan dua kejadian alam yang kejadiannya silih berganti dan bahkan selalu mengancam beberapa daerah di Indonesia. Kekeringan yang terjadi tahun 1972 khususnya di daerah Kedu Selatan sebagai akibat berkurangnya curah hujan masih belum dapat diketahui tingkat kekeringannya. Palmer (1965) telah mencoba memanfaatkan data iklim berupa curah hujan, suhu udara, dan kelengasan tanah sebagai peubah penduga tingkat kekeringan di suatu wilayah yang selanjutnya disebut Indeks kekeringan (Drought Index).

Indeks Kekeringan ini dapat digunakann sebagai salah satu ukuran untuk menentukan perubahan tingkat kekeringan pada suatu daerah. Metode tersebut yang menggunakan prinsip neraca air telah digunakan meluas di Amerika Serikat dan di beberapa kawasan dunia. Hasil yang dilaporkan penunjukkan keadaan yang tidak terlalu menyimpang dari keadaan sebenarnya (Hounam et al, 1975).

Memperhatikan uraian di atas, telah dilakukan suatu penelitian untuk mengevaluasi sebaran tingkat kekeringan yang pernah terjadi di daerah Kedu Selatan, Jawa Tengah dengan menggunakan Indeks Palmer. Daerah ini meliputi tiga zone, morfologi, yaitu zone beting pantai, zone dataran pantai, dan daerah lereng selatan pegunungan Serayu. Perbedaan topografi lokal, elevasi, jarak dari laut, jenis tanah, dan perbedaan vegetasi (penggunaan lahan) akan mencirikan 
suatu tempat berbeda tingkat kekeringannya terhadap tempat lainnya.

\section{Tujuan dan Manfaat Penelitian}

Tujuan penelitian ini antara lain ialah:

1. Mengevalusai kekeringan di daerah Kedu Selatan dengan menggunakan Indeks Palmer.

2. Memperoleh gambaran hubungan antara curah hujan dan Indeks Kekeringan.

Hasil penelitian ini diharapkan berguna bagi usaha pengembangan pertanian di daerah Kedu Selatan dan dapat pula dijadikan bahan pertimbangan untuk pembuatan Peta Indeks kekeringan di Indonesia. Dengan melihat Peta Indeks kekeringan dapat diketahui lebih cepat daerah-daerah yang kekurangan air maupun yang kelebihan air.

\section{BAHAN DAN METODE}

\section{Data dan Peralatan}

Jenis data yang diperlukan dalam penelitian ini adalah:

1. Curah hujan dan suhu udara rataan bulanan selama 5 tahun (1972-19760. Data hujan diperoleh dari 69 stasiun yang tersebar di daerah penelitian, sedang data suhu udara diperoleh dari stasiun Sempor.

2. Jenis tanah (terutama tekstur tanah) dan penggunaan lahan.

3. Sistem pola tanam dan data produksi pertanian.

4. Elevasi dan letak lintang setiap stasiun penakar hujan.

5. Berbagai peta, antara lain ialah peta topografi berskala 1: 50.000 , peta tanah dan peta penggunaan lahan berskala 1: 250.000 , peta iklim, dan peta jaringan poligon Thiessen.

Pengolahan data sebagian dikerjakan bantuan komputer. Selain itu diperlukan pula data air tersedia (availability water) dari setiap tanah yang mempunyai perbedaan tekstur tanah dan vegetasi.

\section{Metode Penelitian}

Data curah hujan, suhu udara, dan air tanah tersedia sebagai masukan pertama pada komputer. Program komputer meliputi tiga tahap perhitungan, yaitu (1) perhitungan neraca air, (2) perhitungan koefisien "iklim", dan (3) perhitungan indeks kekeringan.

Setiap stasiun hujan mewakili luasan daerah tertentu yang dibatasi oleh poligon, sedangkann suhu udara digunakan untuk menghitung evapotranspirasi potensial metode Thornthwaite. Pendugaan air tersedia dalam tanah didekati dengan cara sebagai berikut:

1. Tampalkan tiga peta yang berskala sama dengan urutan dari bawah ke atas adalah peta penggunan lahan, peta tanah dan peta jaringan poligon,

2. Menghitung luas setiap bentuk penggunaan lahan pada suatu poligon dengan mempertimbangkan tekstur tanahnya,

3. Berdasarkan tekstur tanah, maka dapat ditentukan air tanah tersedia ( $\mathrm{s}$ atuan $\mathrm{mm} / \mathrm{m}$ ). Dengan memperhitungkan setiap kedalaman lapisan tanah, maka air tersedia pada masing-masing lapisan tanah dapat diketahui (satuan dalam mm). 


\section{Dasar Pemikiran metode Palmer}

Konsep neraca air digunakan oleh Palmer untuk menentukan indeks kekeringan. Dalam analisisnya Palmer menggunakan model dua lapisan tanah. Parameter yang dimasukkan adalah curah hujan, evapotranspirasi potensial, da air tanah tersedia. Nilai potensial juga diperlukan bagi limpasan (runoff), pegisian lengas tanah (recharge), dan kehilangan air (loss). Hasil perhitungan neraca air digunakan untuk menentukan keempat koefisien bulanan, yaitu koefisien evapotranspirasi ( $\alpha$ ), koefisien "recharge" $(\beta)$, koefisien limpasan $(\gamma)$, kefisien " $\beta$ se" ( S ), dan karakteristik iklim ( $\mathrm{K}$ ).

Sedangkan konsep yang mendasari batasan kekeringan adalah bahwa curah hujan yang dibutuhkan untuk mencapai keadaan normal pada suatu periode tertentu di suatu tempat ditentukan oleh rataan "iklim" dan kondisi cuaca selama dan sebelum periode yang telah ditentukan. Perbedaan nilai antara curah hujan teratur dan hasil perhitungan digunakan sebagai ukuran penyimpangan dari keadaan normal (Palmer 1965).

\section{Metode Penggambaran}

Peta Indeks Kekeringan pada bulan-bulan tertentu dibuat berdasarkan nilai (indeks) kekeringan dari 69 statiun. Penarikan garis "iso-kekeringan" disebut dengan metode interpolasi linear. Pada daerah-daerah yang bergelombang, penggambarannya dilakukan dengan mempertimbangkan faktor topografi dan faktor lingkungan fisik lainnya.

\section{Hubungan antara Curah Hujan dan Indeks Kekeringan}

Keeratan hubungan antara kedua peubah tersebut di atas ditunjukkan oleh koefisien korelasinya. Menurut Panofsky dan Brier (1958) rumus yang diguakan adalah korelasi-silang (cross-correlations) atau dengan lag cross-correlations.

Rumus yang digunakan adalah:

$r=\frac{P(t) \cdot X((t)-X(t) \cdot X(t)}{s p \cdot s x}$
dan
$P t \cdot X t+L-P(t 0 \cdot X(t)$
$r L=\frac{\text { sp. } s X}{}$

adapun:

$\mathrm{r}$ : koefisien korelasi

$\mathrm{rl}:$ koefisien korelasi-lag

$\mathrm{P}(\mathrm{t} 0$ : curah hujan pada waktu ke-t

$\mathrm{X}(\mathrm{t})$ : indek kekeringan pada waktu ke-t

$\mathrm{Xt}+\mathrm{L}$ : indeks kekeringan pada waktu ke $\mathrm{t}+\mathrm{L}$

$\mathrm{sp}$ : simpangan baku data curah hujan $\mathrm{sx}$ : simpangan baku data indeks kekeringan

\section{Verifikasi Peta Indeks Kekeringan}

Veritifikasi (pengujian) Peta Indeks Kekeringan yang dihasilkan dilakukan terhadap data produksi pertanian (khususnya produksi padi ladang) maupun peristiwa banjir dan serangan hama-penyakit tanaman yang pernah terjadi di daerah peneltian.

\section{HASIL DAN PEMBAHASAN}

\section{Pola Indeks kekeringan}

Secara umum kekeringan yang terjadi pada tahun 1972 mencapai puncaknya pada bulan Oktober dan Nopember. Curah hujan menurun 


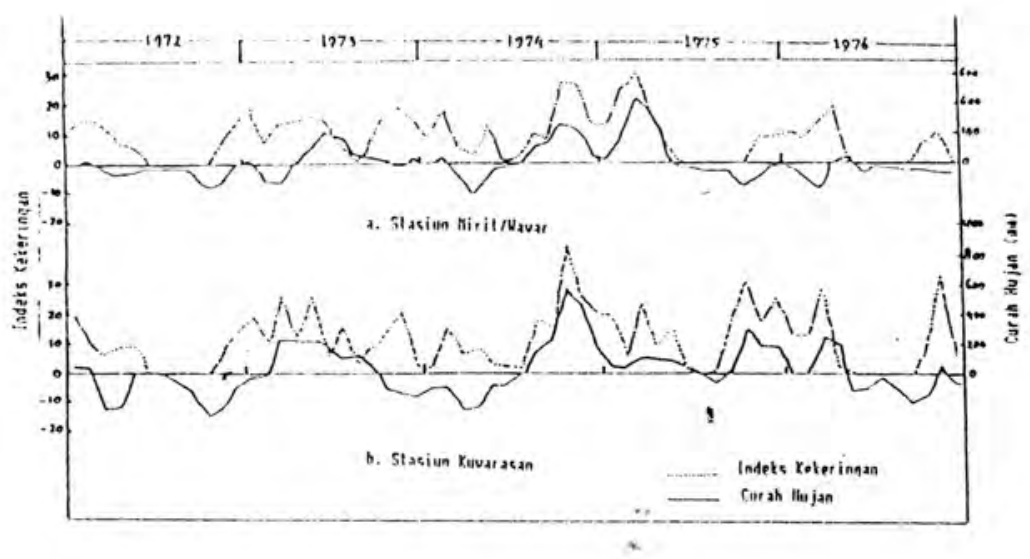

Gambar 1.

Hubungan antara Curah Hujan dan Indeks Kekeringan antara Tahun 1972-1976 (a) Stasiun Mirit dan (b Stasiun Kuwarasan

jumlahnya mulai Februari dan bahkan tidak terajdi hujan terus-menerus selama 4 bulan. Hal ini mengakibatkan indeks kekeringan mencapai nilai negatip terbesar (terkering). Bila nilai indeks kekeringan nol dianggap sebagai keadaan normal, maka indeks keadaan basah atau keadaan kering mencapai maksimum terjadi di Wadaslintang yaitu sebesar + 75 (Nopember 1975) dan -26 (Nopember 1972).

Untuk mengetahui pengaruh curah hujan terhadap indeks kekeringan, diibuatkan suatu grafik fluktuasi curah hujan dan indeks kekeringan di beberapa stasiun terpilih dari tahun 1972 hingga 1976. Gambaran ini merupakan dua deret berkala (time series) yang dapat dihitung koefisien korelasinya. Salah satu contoh disajikan pada gambar 1a dan $1 b$.
Pada gambar 1a dan $1 \mathrm{~b}$ di atas nampak ada kecenderungan yang hampir sama antara fluktuasi curah hujan dan indeks kekeringan. Korelasi kedua pubah tersebut dihitung dengan rumus korelasi silang. Pada gambar tersebut juga terlihat bahwa pengaruh curah hujan pada waktu ke-t baru akan nampak pengaruhnya terhadap indeks kekeringan pada waktu ke $t+1$. Dengan mengambil asumsi tenggang waktu (time-lag) paling lama di daerah penelitian satu bulan, maka dalam perhitungan dilakukan terhadap jumlah dara N-1. Gejala kemunduran pengaruh tersebut dijumpai di daerah Somogede, yaitu kekeringan yang terjadi akhir tahun 1973 dan akhir tahun 1976. Dalam kasus seperti ini korelasinya dihitung dengan rumus lag cross-correlations. Selanjutnya untuk mengetahui korelasi yang tertinggi antara $\mathrm{r}$ dan $\mathrm{rL}$ dapat dilihat pada Tabel 1. 
Tabel 1.

Koefisien Korelasi antara Curah Hujan

dan Indeks Kekeringan di Beberapa

Stasiun di Kedu Selatan

\begin{tabular}{lll}
\hline Nama Stasiun & $\mathrm{r}$ & $\mathrm{rL}$ \\
\hline & & \\
Wawas/Mirit & 0.57 & 0,55 \\
Kuwarasan & 0.65 & 0,54 \\
Jrakah & 0,48 & 0,43 \\
Somogede & $0,56^{*}$ & $0,61^{*}$ \\
Wadaslintang & 0,66 & 0,54 \\
Sapuran & 0,72 & 0,71 \\
\hline & & \\
$*$ rL $>\mathrm{r}$ & &
\end{tabular}

Sebagian besar nilai $r$ selalu lebih tinggi daripada nilai rL, kecuali di Somogede. Hal ini berarti bahwa kekeringan yang terjadi di Somogede timbulnya lebih lambat dibandingkan dengan daerah-daerah lainnya. Peranan hutan dalam menjaga kelestarian air dari waktu ke waktu nampak nyata sekali. Hutan di Somogede seluas 71 persen sedangkan daerah lainnya kurang dari 50 persen, bahkan di beberapa tempat tidak dijumpai hutan.

\section{Verifikasi Indeks Kekeringan}

Kekeringan yang pernah terjadi tahun 1972 hampir dijumpai di seluruh daerah penelitian. Williams dan Josep (1975) menyatakan bahwa salah satu faktor menurunnya produksi tanaman disebabkan oleh kekeringan. Namun tidaklah selalu demikian, masih banyak faktor yang mempengaruhinya, misalnya serangan hama/penyakit, banjir (genangan), maupun malapetaka yang tak diduga sebelumnya.
Kalau serangan hama dan penyakit dapat di atasi dengan memberikan insektisida dan pestisida, kebanjiran dapat diatasi dengan membuat saluran drainase, maka irigasi dilakukan untuk mengatasi kekurangan air. Namun dalam prakteknya sistem irigasi ini tidak dapat menjangkau seluruh daerah yang membutuhkan air, sehingga masih terdapat daerah pertanian lahan kering seluas $934,81 \mathrm{~km}^{2}$ atau kira-kira 33 persen luas dari daerah penelitian.

Salah, satu faktor yang dapat dijadikan sebagai indikator kekeringan di daerah ini adalah menurunnya produksi pertanian khususnya produksi padi ladang. Fluktuasi peroduksi padi ladang tahun 1969 hingga 1975 disajikan pada Tabel 2. 
Tabel 2. Luas Panen, Rataan Produksi, dan Produksi

Padi Ladang di Kabupaten Kebumen dan Purworejo dari Tahun 1969-1975a)

\begin{tabular}{|c|c|c|c|c|c|c|}
\hline \multirow[t]{2}{*}{ Tahun } & \multicolumn{3}{|c|}{ Kabupaten Kebumen } & \multicolumn{3}{|c|}{ Kebupaten .Purworejo } \\
\hline & $\begin{array}{l}\text { Luas } \\
\text { Panen } \\
\text { (ha) }\end{array}$ & $\begin{array}{l}\text { Rataan } \\
\text { Produksi } \\
\text { (kw/ha) }\end{array}$ & $\begin{array}{l}\text { Eroduksi } \\
(\mathrm{k} w)\end{array}$ & $\begin{array}{l}\text { Luas } \\
\text { Panen } \\
\text { (ha) }\end{array}$ & $\begin{array}{l}\text { Rataan } \\
\text { Produksi } \\
\text { (kw/ha) }\end{array}$ & $\begin{array}{l}\text { Eroduksi } \\
(k w)\end{array}$ \\
\hline 1969 & 2.611 & 16,40 & 42.820 & 633 & 16,40 & 10.381 \\
\hline 1970 & 4.722 & 16,75 & 79.141 & 821 & 16,76 & 13.760 \\
\hline 1971 & 3.602 & 16,15 & 58.193 & 861 & 19,08 & 15.423 \\
\hline 1372 & 1.663 & 19,05 & $31.682 *)$ & 647 & 17,24 & $11.154^{*}$ ) \\
\hline 1973 & 5.833 & 20,56 & 119.925 & 601 & 25,28 & 15.131 \\
\hline 1974 & 2.318 & 19,68 & 45.610 & 522 & 22,73 & 11.870 \\
\hline 1975 & 2.304 & 26,78 & 61.710 & 403 & 22,06 & 8.890 \\
\hline
\end{tabular}

a) - Dinas Pertanian Kab. Kebumen dan Kab. Purworejo

- Biro Pusat Statistik, Jakarta

*) Ter.jadi penurunan produksi.

Penurunan produksi padi ladang tahun 1972 diduga disebabkan oleh kekeringan yang meluas di daerah penelitian. Hal ini dapat dilihat pada Gambar 2. Sedangkan penurunan produksi padi ladang tahun 1974 dan 1975 diduga sebagai akibat kelebihan air (banjir). Meskipun penurunan produksi padi ladang di Purworejo tidak setajam yang terjadi di Kebumen.

Proyek Serbaguna Kedu Selatan (Proyek Karangsambung) pernah memetakan daerah genangan banjir tanggal 23 Nopember 1974 (lihat Gambar 3). Kejadian ini dapat pula dijadikan petunjuk bahwa penurunan peroduksi padi ladang kemungkinan disebabkan oleh banjir yang melanda daerah versebut.

\section{$\overline{\text { KESIMPULAN }}$}

Hasil penggambaran dua deret waktu (curah hujan dan indeks kekeringan) menunjukkan kecenderungan fluktuasi yang hampir sama. Daerah-daerah yang sebagian besar wilayahnya tertutup hutan akan mengakibatkan kemunduran waktu timbulnya kekeringan. Namun koefisien korelasi kedua cubah tersebut untuk nilai $\mathrm{r}$ selalu lebih tinggi daripada $\mathrm{rL}$, kecuali di daerah Somogede.

Hasil verifikasi Peta Indeks kekeringan dapat dikaitkan dengan data produksi pertanian (padi ladang) dan perisitiwa banjir yang pernah terjadi. 


\section{DAFTAR PUSTAKA}

Chambers, R.E., Kisdarto, dan M. B1. de Rozari. 1979. Thought on agroclimatological classification. Makalah No. 22 dalam Simposium Meteorologi Pertanian, Bogor.,

Haunam, C.E. et. al. 1975. Drought and Agriculture. Technical Note No. 138. WHO No. $392 \mathrm{~m}$ Geneva.

Palmer, W.C. 1965. Meteorological Drought. Research Paper No. 45. US-Weather Bureau. Washington D.C.

Panofsky, H. A. and G.W. Brier. 1958. Some Applications of Statistics to Meteorology. University Park, Pennsylvania.

Rijks, J.Q. 1979. Agrometeorology for Agriculture with Minimum Rainfall. Makalah dalam Simpsium Meteorologi Pertanian, Bogor.

Sudibyakto. 1985. Evaluasi Kekeringan di Daerah kedu Selatan, Jawa Tengah Dengan menggunakan indeks Palmer. Tesis magister Sains. Fakultas Pascasarjana IPB, Bogor. 